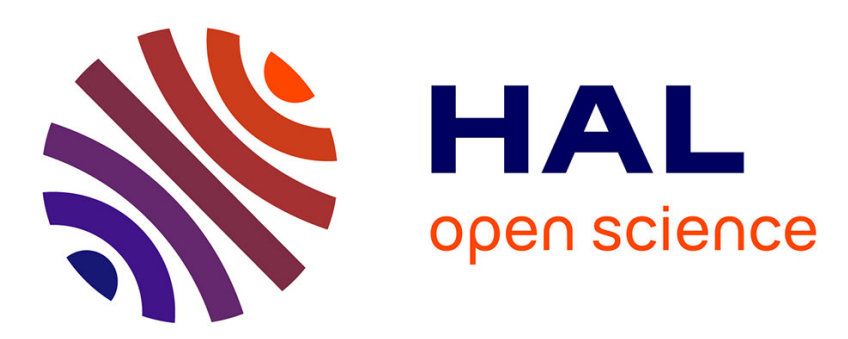

\title{
Deprotonative metalation of substituted aromatics using mixed lithium-cobalt combinations
}

\author{
Gandrath Dayaker, Floris Chevallier, Philippe C. Gros, Florence Mongin
}

\section{To cite this version:}

Gandrath Dayaker, Floris Chevallier, Philippe C. Gros, Florence Mongin. Deprotonative metalation of substituted aromatics using mixed lithium-cobalt combinations. Tetrahedron, 2010, 66, pp.8904-8910. 10.1016/j.tet.2010.09.053 . hal-01010453

HAL Id: hal-01010453

https://hal-univ-rennes1.archives-ouvertes.fr/hal-01010453

Submitted on 19 Jun 2014

HAL is a multi-disciplinary open access archive for the deposit and dissemination of scientific research documents, whether they are published or not. The documents may come from teaching and research institutions in France or abroad, or from public or private research centers.
L'archive ouverte pluridisciplinaire HAL, est destinée au dépôt et à la diffusion de documents scientifiques de niveau recherche, publiés ou non, émanant des établissements d'enseignement et de recherche français ou étrangers, des laboratoires publics ou privés. 


\section{Graphical Abstract}

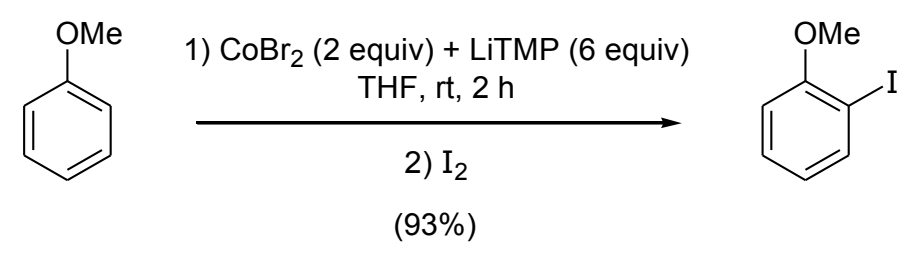

\section{Deprotonative metalation of substituted aromatics using mixed lithium-cobalt combinations}

Gandrath Dayaker, ${ }^{\dagger}$ Floris Chevallier, ${ }^{\dagger}$ Philippe C. Gros,${ }^{\dagger}$ and Florence Mongin* ${ }^{\dagger}{ }^{\dagger}$

${ }^{\dagger}$ Chimie et Photonique Moléculaires, UMR 6510 CNRS, Université de Rennes 1, Bâtiment 10A, Case 1003, Campus Scientifique de Beaulieu, 35042 Rennes, France, ${ }^{\star}$ SOR, SRSMC, CNRS, Nancy Université, Boulevard des Aiguillettes, 54506 Vandouvre-les-Nancy, France

* To whom correspondence should be addressed. E-mail: florence.mongin@univ-rennes1.fr. Phone: +3322323 6931. Fax: +33223236955. 


\begin{abstract}
:
The deprotonation of anisole was attempted using different homo- and heteroleptic TMP/Bu mixed lithium-cobalt combinations. Using iodine to intercept the metalated anisole, an optimization of the reaction conditions showed that in $\mathrm{THF}$ at room temperature 2 equiv of base were required to suppress the formation of the corresponding 2,2'-dimer. The origin of the dimer was not identified, but its formation was favored with allyl bromide as electrophile. The metalated anisole was efficiently trapped using iodine, anisaldehyde, and chlorodiphenylphosphine, and moderately employing benzophenone, and benzoyl chloride. 1,2-, 1,3- and 1,4-dimethoxybenzene were similarly converted regioselectively to the corresponding iodides. It was observed that 2-methoxy- and 2,6-dimethoxypyridine were more prone to dimerization than the corresponding benzenes when treated similarly. Involving ethyl benzoate in the metalation-iodination sequence showed the method was not suitable to functionalize substrates bearing reactive functions.
\end{abstract}

\title{
Keywords:
}

bimetallic bases, deprotonative metalation, aromatic compounds, lithium, cobalt

\section{Introduction}

The deprotonative metalation using lithium bases has been widely used as a powerful method for the regioselective functionalization of aromatic compounds. ${ }^{1}$ The use of metal additives in order to get more efficient or more chemoselective bases (synergic superbases) is a challenging field. Pioneer studies, respectively carried out in the groups of Schlosser ${ }^{2}$ and Lochmann ${ }^{3}$ with LIC-KOR, mixture of butyllithium (LIC) and potassium tert-butoxide (KOR), and by Caubère, Gros and Fort ${ }^{4}$ in the pyridine series with BuLi-LiDMAE (DMAE = 2-dimethylaminoethoxide) and $\mathrm{Me}_{3} \mathrm{SiCH}_{2} \mathrm{Li}$-LiDMAE merged alkyllithiums and alkali-metal alkoxides. More recently, the use of other $(R)_{n}\left(R^{\prime}\right)_{n}$ 'MLi-type bases, with $\mathrm{M}$ being different from an alkali-metal (e.g. $\mathrm{M}=\mathrm{Mg}, \mathrm{Al}, \mathrm{Cr}, \mathrm{Mn}, \mathrm{Cu}, \mathrm{Zn}$ ), has been described by different groups for their ability to deprotonate aromatic compounds, ${ }^{5}$ and notably anisole. ${ }^{6}$ In 2009 , Klett, Mulvey and co-workers showed that it is possible to design sodium-iron(II) bases, and extended 
the ability to deprotonate to group 8 ate compounds. ${ }^{7}$ The same year, Wunderlich and Knochel showed that ferration can be achieved using salt-solubilized $(\mathrm{TMP})_{2} \mathrm{Fe} \cdot 2 \mathrm{MgCl}_{2} \cdot 4 \mathrm{LiCl}(\mathrm{TMP}=2,2,6,6-$ tetramethylpiperidino). ${ }^{8}$

We recently accomplished the room temperature deproto-metalation of a large range of substrates including sensitive heterocycles and functionalized benzenes using newly developed lithium-zinc, ${ }^{9}$ lithium-cadmium, ${ }^{10}$ and lithium-copper(I) ${ }^{11}$ combinations, in situ prepared from $\mathrm{MCl}_{2} \cdot \mathrm{TMEDA}(\mathrm{M}=$ $\mathrm{Zn}, \mathrm{Cd}$ or $\mathrm{Cu}, \mathrm{TMEDA}=N, N, N^{\prime}, N^{\prime}$-tetramethylethylenediamine) and lithium reagents (alkyllithiums or lithium amides). The studies performed using lithium-zinc and lithium-cadmium combinations have notably shown that the more efficient bases were obtained by mixing the metal salt with 3 equiv of LiTMP. ${ }^{9 \mathrm{~d}, 10 \mathrm{~g}}$ A main drawback of the methods developed being the lack of reactivity of such generated arylmetals in direct trapping with electrophiles, we turned to other bimetallic combinations in order to identify candidates able to perform efficient deprotonations, but also to allow direct functionalizations. We here describe the first aromatic deproto-metalations using lithium-cobalt combinations.

\section{Results and Discussion}

The synthesis of organocobalt ate compounds is well-documented in the literature. They are in general obtained by transmetalation of organolithium $^{12}$ or -magnesium ${ }^{13}$ reagents with cobalt(II) halides. Examples are $\mathrm{Me}_{3} \mathrm{CoLi},{ }^{12 \mathrm{a}} \mathrm{Me}_{4} \mathrm{CoLi}_{2}(\mathrm{TMEDA})_{2}{ }^{12 \mathrm{~b}}$ and $\left(\mathrm{R}_{3} \mathrm{SiCH}_{2}\right)_{4} \mathrm{Co}(\mathrm{MgCl})_{2}\left(\mathrm{R}_{3} \mathrm{Si}=\mathrm{Me}_{3} \mathrm{Si}\right.$, $\left.\mathrm{MePh}_{2} \mathrm{Si},{ }^{t} \mathrm{BuMe}_{2} \mathrm{Si}\right) .{ }^{13}$ The access to mixed lithium-cobalt amides is far less documented, but seems possible similarly. ${ }^{14}$ We first consider the use of $\mathrm{CoCl}_{2} \cdot \mathrm{TMEDA}$ chelate ${ }^{15}$ in order to manipulate a salt less hygroscopic than $\mathrm{CoCl}_{2}$, but attempts to prepare it failing in giving good microanalyses, we turned to $\mathrm{CoBr}_{2}{ }^{16}$ We prepared different lithium-cobalt combinations by mixing the cobalt salt with 3 or 4 equiv of a lithium compound, either LiTMP or mixtures with butyllithium, at $0{ }^{\circ} \mathrm{C}$. We chose anisole (1) as substrate to check the ability to deprotonate of the mixtures (Table 1).

Using LiTMP ( 1 equiv) or (TMP) ${ }_{2} \mathrm{Co}$ (1 equiv, in situ generated from $\mathrm{CoBr}_{2}$ and 2 equiv of LiTMP) in tetrahydrofuran (THF) at room temperature for $2 \mathrm{~h}$, and then iodine, anisole (1) was converted into 
the 2-iodo derivative $\mathbf{2 a}$ in 9 or $0 \%$ yield, respectively. In contrast, when treated with an in situ prepared mixture of $\mathrm{CoBr}_{2}$ (1 equiv) and LiTMP (3 equiv) at $25^{\circ} \mathrm{C}$ for $2 \mathrm{~h}$, anisole (1) was readily orthometalated, a result evidenced with the formation of $\mathbf{2 a}$ in $54 \%$ yield after purification (Entry 1). Lowering the reaction temperature to $0{ }^{\circ} \mathrm{C}$ resulted in a low conversion, even after $4 \mathrm{~h}$ reaction time (Entries 2 and 3). When performed at $45^{\circ} \mathrm{C}$, the metalation step worked as at $25^{\circ} \mathrm{C}$, affording $2 \mathbf{a}$ in $50 \%$ yield (Entry 4). It is known that labile ligands can play a role on the course of reactions. ${ }^{9 a}$ To check a possible effect, the reaction was performed at room temperature in the presence of 1 equiv of TMEDA; the 39 and 59\% yields respectively obtained with and without TMEDA indicates the deleterious influence of this ligand, uninteresting in this case (Entry 5). The impact of the reaction time was next considered. It was observed that reducing the reaction time to $30 \mathrm{~min}$ resulted in a lower $43 \%$ yield (Entry 6). Extending the reaction time to $4 \mathrm{~h}$ did not bring any improvement (Entry 7 ), but after 20 $\mathrm{h}$ the yield was significantly reduced to $38 \%$ (Entry 8 ). The effect of the base amount was then studied. Using 0.5 equiv of $\mathrm{CoBr}_{2}$ and 1.5 equiv of LiTMP led to low conversions, whatever the reaction time (Entry 9). It was possible to find again the 54\% yield already obtained Entry 1 by using 1.5 equiv of $\mathrm{CoBr}_{2}$ and 4.5 equiv of LiTMP, and a 30 min reaction time (Entry 10). The best result (93\% yield) was obtained using 2 equiv of $\mathrm{CoBr}_{2}$ and 6 equiv of LiTMP (Entry 11), allowing to reduce the reaction time to $30 \mathrm{~min}$ (Entry 12).

As previously noted in a lesser extent in other bimetallic series, ${ }^{9 \mathrm{~d}, 10 \mathrm{~g}}$ putative $\mathrm{Bu}_{3} \mathrm{CoLi} \cdot 2 \mathrm{LiBr}($ Entry 13), $\mathrm{Bu}_{2} \mathrm{Co}(\mathrm{TMP}) \mathrm{Li} \cdot 2 \mathrm{LiBr}($ Entry 14$)$, and $\mathrm{BuCo}(\mathrm{TMP})_{2} \mathrm{Li} \cdot 2 \mathrm{LiBr}($ Entry 15$)$ alkyl/amino combinations are not able to deprotonate anisole (1). Higher-order ate compounds being in general more reactive than lower-order ones, ${ }^{17}$ reactions were attempted using putative $\mathrm{Bu}_{3} \mathrm{Co}(\mathrm{TMP}) \mathrm{Li}{ }_{2} \cdot 2 \mathrm{LiBr}$ (Entry 16), $\mathrm{Bu}_{2} \mathrm{Co}(\mathrm{TMP})_{2} \mathrm{Li}_{2} \cdot 2 \mathrm{LiBr}$ (Entry 17$)$, and $\mathrm{BuCo}(\mathrm{TMP})_{3} \mathrm{Li}_{2} \cdot 2 \mathrm{LiBr}$ (Entry 18). The iodide $\mathbf{2 a}$ was only isolated in $19 \%$ yield in the last reaction, due to the competitive formation of 2,2'-dimethoxybiphenyl (3) in 35\% yield. 
The formation of the dimer 3 has been observed in all the experiments where metalation took place, but in various yields. Its formation does not seem to depend on the deprotonation temperature (Entries 1-4), but seems to be favored with long contact times (Entry 8). In addition, it is clear that the use of 2 equiv of base prevents its formation (Entries 11 and 12), as if it formed intramolecularly. Using water instead of iodine to trap the metalated anisole derivative also resulted in the formation of $\mathbf{3}$ in a similar 14\% yield (Entry 19). Thus, if cross-coupling with the iodide $2,^{12 c, 18}$ and iodine-mediated oxidation ${ }^{19}$ can be proposed to explain the formation of $\mathbf{3}$, alternatives ways without recourse to them exist. A possible in situ partial reduction of $\mathrm{Co}(\mathrm{II})$ species to $\mathrm{Co}(\mathrm{I})$ due to the presence of metal amides is possible, ${ }^{20}$ but would not lead to a dimer in the absence of an halide. ${ }^{21}$ Even if the use of degassed THF did not change significantly the result (Entry 19), ${ }^{22}$ a possible role of dissolved oxygen cannot be ruled out. ${ }^{19}$ An alternative explanation could be the presence of a metal impurity in $\mathrm{CoBr}_{2}$ for which the corresponding diaryl metal ate compounds is prone to dimerization. Using allyl bromide instead of iodine (or water) to quench the metalated anisole derivative produced the dimer 3 in $38 \%$ yield, and 2allylanisole (2b) in 6\% yield besides (Entry 20). One-electron transfers from cobalt(II) ate compounds to allyl bromide are possible pathways, ${ }^{23}$ and dimerization from the generated Co(III) species bearing two aryl groups ${ }^{18 \mathrm{a}}$ appears as a possible pathway to explain the formation of $\mathbf{3}$ in this case (Scheme 1). Other electrophiles favor the dimerization. For example, the use of 2-bromopyridine in order to convert the metalated anisole into the cross-coupling product 2c was similarly threatened by a significant formation of $\mathbf{3}$ (Entry 21).

\section{SCHEME 1. Possible pathway for the formation of 3 from the metalated anisole derivative.}

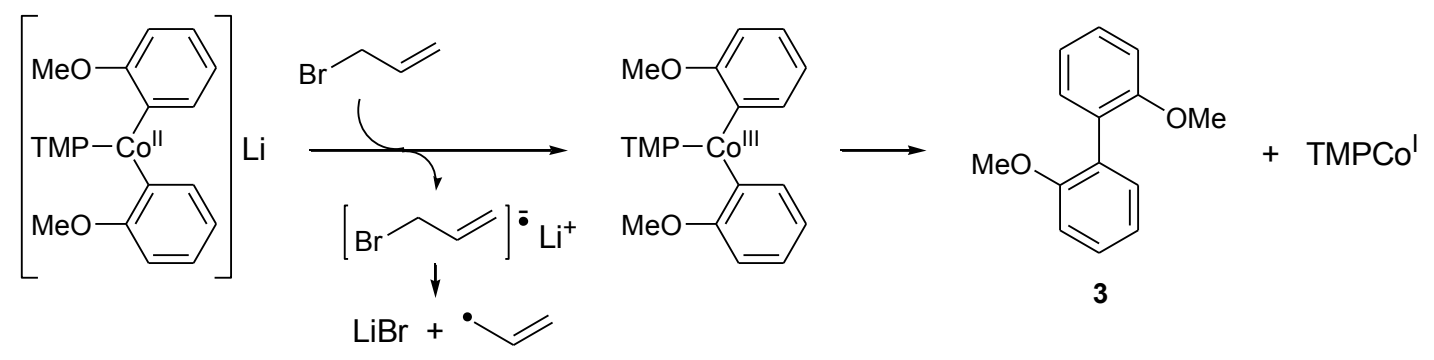


TABLE 1. Optimization of Anisole Metalation using a Lithium/Cobalt Base.
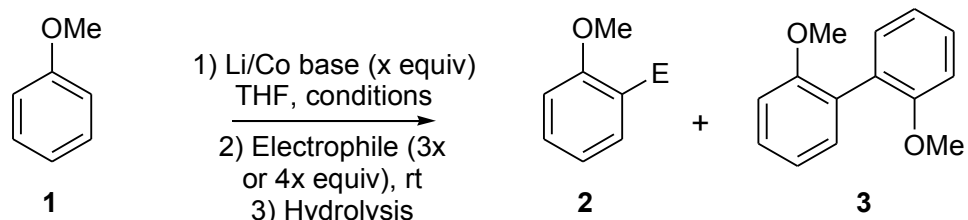

\begin{tabular}{|c|c|c|c|c|c|}
\hline entry & Li/Co base $(x)$ & conditions & $\begin{array}{l}\text { electrophile } \\
(3 x \text { or } 4 x)\end{array}$ & $2(\mathrm{E})$, yield & $\begin{array}{l}\text { yield } \\
\text { of } \mathbf{3}^{a}\end{array}$ \\
\hline $1^{b}$ & $\mathrm{CoBr}_{2}(1)+\operatorname{LiTMP}(3)$ & $25^{\circ} \mathrm{C}, 2 \mathrm{~h}$ & $\mathrm{I}_{2}(3)$ & $2 a(I), 54 \%$ & $17 \%$ \\
\hline 2 & $\mathrm{CoBr}_{2}(1)+\operatorname{LiTMP}(3)$ & $0^{\circ} \mathrm{C}, 2 \mathrm{~h}$ & $\mathrm{I}_{2}(3)$ & $\mathbf{2 a}(\mathrm{I}), 12 \%$ & $5 \%$ \\
\hline 3 & $\mathrm{CoBr}_{2}(1)+\operatorname{LiTMP}(3)$ & $0^{\circ} \mathrm{C}, 4 \mathrm{~h}$ & $\mathrm{I}_{2}(3)$ & $\mathbf{2 a}(\mathrm{I}), 13 \%$ & $24 \%$ \\
\hline 4 & $\mathrm{CoBr}_{2}(1)+\operatorname{LiTMP}(3)$ & $45^{\circ} \mathrm{C}, 2 \mathrm{~h}$ & $\mathrm{I}_{2}(3)$ & $\mathbf{2 a}(\mathrm{I}), 49 \%$ & $20 \%$ \\
\hline 5 & $\mathrm{CoBr}_{2}(1)+\operatorname{LiTMP}(3)$ & $\mathrm{rt}^{c}, 2 \mathrm{~h}$ & $\mathrm{I}_{2}(3)$ & $\mathbf{2 a}(\mathrm{I}), 59 \%^{d}$ & $-e$ \\
\hline 6 & $\mathrm{CoBr}_{2}(1)+\operatorname{LiTMP}(3)$ & $\mathrm{rt}, 30 \mathrm{~min}$ & $\mathrm{I}_{2}(3)$ & $2 \mathbf{a}(\mathrm{I}), 43 \%$ & $21 \%$ \\
\hline 7 & $\mathrm{CoBr}_{2}(1)+\operatorname{LiTMP}(3)$ & $\mathrm{rt}, 4 \mathrm{~h}$ & $\mathrm{I}_{2}(3)$ & $\mathbf{2 a}(\mathrm{I}), 57 \%$ & $-e$ \\
\hline 8 & $\mathrm{CoBr}_{2}(1)+\operatorname{LiTMP}(3)$ & $\mathrm{rt}, 20 \mathrm{~h}$ & $\mathrm{I}_{2}(3)$ & $\mathbf{2 a}(\mathrm{I}), 38 \%$ & $34 \%$ \\
\hline 9 & $\mathrm{CoBr}_{2}(0.5)+\operatorname{LiTMP}(1.5)$ & rt, 2 to $20 \mathrm{~h}$ & $\mathrm{I}_{2}(1.5)$ & $\mathbf{2 a}(\mathrm{I}),-f$ & $f$ \\
\hline 10 & $\mathrm{CoBr}_{2}(1.5)+\operatorname{LiTMP}(4.5)$ & $\mathrm{rt}, 30 \mathrm{~min}$ & $\mathrm{I}_{2}(4.5)$ & $2 \mathbf{a}(\mathrm{I}), 54 \%$ & $16 \%$ \\
\hline 11 & $\mathrm{CoBr}_{2}(2)+\operatorname{LiTMP}(6)$ & $\mathrm{rt}, 2 \mathrm{~h}$ & $\mathrm{I}_{2}(6)$ & $\mathbf{2 a}(\mathrm{I}), 93 \%$ & $-e$ \\
\hline 12 & $\mathrm{CoBr}_{2}(2)+\operatorname{LiTMP}(6)$ & $\mathrm{rt}, 30 \mathrm{~min}$ & $\mathrm{I}_{2}(6)$ & $\mathbf{2 a}(\mathrm{I}), 93 \%$ & $5 \%$ \\
\hline 13 & $\mathrm{CoBr}_{2}(1)+\mathrm{BuLi}(3)$ & $\mathrm{rt}, 2 \mathrm{~h}$ & $\mathrm{I}_{2}(3)$ & $\mathbf{2 a}(\mathrm{I}), 0 \%$ & $0 \%$ \\
\hline 14 & $\mathrm{CoBr}_{2}(1)+\operatorname{LiTMP}(1)+\operatorname{BuLi}(2)$ & $\mathrm{rt}, 2 \mathrm{~h}$ & $\mathrm{I}_{2}(3)$ & $\mathbf{2 a}(\mathrm{I}), 0 \%$ & $0 \%$ \\
\hline 15 & $\mathrm{CoBr}_{2}(1)+\operatorname{LiTMP}(2)+\operatorname{BuLi}(1)$ & $\mathrm{rt}, 2 \mathrm{~h}$ & $\mathrm{I}_{2}(3)$ & $\mathbf{2 a}(\mathrm{I}), 0 \%$ & $0 \%$ \\
\hline 16 & $\mathrm{CoBr}_{2}(1)+\operatorname{LiTMP}(1)+\operatorname{BuLi}(3)$ & $\mathrm{rt}, 2 \mathrm{~h}$ & $\mathrm{I}_{2}(4)$ & $\mathbf{2 a}(\mathrm{I}), 0 \%$ & $0 \%$ \\
\hline 17 & $\mathrm{CoBr}_{2}(1)+\operatorname{LiTMP}(2)+\operatorname{BuLi}(2)$ & $\mathrm{rt}, 2 \mathrm{~h}$ & $\mathrm{I}_{2}(4)$ & $\mathbf{2 a}(\mathrm{I}), 0 \%$ & $0 \%$ \\
\hline 18 & $\mathrm{CoBr}_{2}(1)+\operatorname{LiTMP}(3)+\mathrm{BuLi}(1)$ & $\mathrm{rt}, 2 \mathrm{~h}$ & $\mathrm{I}_{2}(4)$ & $\mathbf{2 a}(\mathrm{I}), 19 \%$ & $35 \%$ \\
\hline 19 & $\mathrm{CoBr}_{2}(1)+\operatorname{LiTMP}(3)$ & $\mathrm{rt}, 2 \mathrm{~h}$ & $\mathrm{H}_{2} \mathrm{O}(3)$ & $1(\mathrm{H}),-$ & $14 \%^{g}$ \\
\hline 20 & $\mathrm{CoBr}_{2}(1)+\operatorname{LiTMP}(3)$ & $\mathrm{rt}, 2 \mathrm{~h}$ & $\mathrm{BrCH}_{2} \mathrm{CH}=\mathrm{CH}_{2}(3)$ & $\mathbf{2 b}\left(\mathrm{CH}_{2} \mathrm{CH}=\mathrm{CH}_{2}\right), 6 \%^{h}$ & $38 \%$ \\
\hline 21 & $\mathrm{CoBr}_{2}(1)+\operatorname{LiTMP}(3)$ & $\mathrm{rt}, 2 \mathrm{~h}$ & & $\%)^{i}$ & $\begin{array}{l}19 \% \\
(26 \%)^{i}\end{array}$ \\
\hline
\end{tabular}

${ }^{a}$ The rest is in general anisole. ${ }^{b} 9$ and $0 \%$ yield using LiTMP and (TMP) ${ }_{2}$ Co, respectively, under the same reaction conditions. ${ }^{c}$ Between 17 and $23{ }^{\circ} \mathrm{C} .{ }^{d} 39 \%$ yield in the presence of 1 equiv of TMEDA. ${ }^{e}$ Not quantified. ${ }^{f}$ Low conversion and significant formation of dimer. ${ }^{g} 12 \%$ using degassed THF. ${ }^{h}$ The high volatility of the compound could be partly responsible for the low yield obtained. ${ }^{i}$ Trapping step performed at $50{ }^{\circ} \mathrm{C}$ instead of $\mathrm{rt}$. 
The optimized conditions in hands, the use of different electrophiles was attempted (Table 2). Anisaldehyde led to the corresponding alcohol $\mathbf{2 d}$ in a satisfying yield (Entry 2). The alcohol $\mathbf{2 e}$ and ketone $\mathbf{2} \mathbf{f}$ were produced in moderate yields upon interception with benzophenone and benzoyl chloride, respectively (Entries 3 and 4). The phosphine $\mathbf{2 g}$ was obtained satisfactorily using chlorodiphenylphosphine, but the cross-coupled derivative $\mathbf{2 c}$ was isolated in a low $25 \%$ yield due to a significant formation of $\mathbf{3}$ (Entry 6 ).

TABLE 2. Electrophilic Trapping of Metalated Anisole.

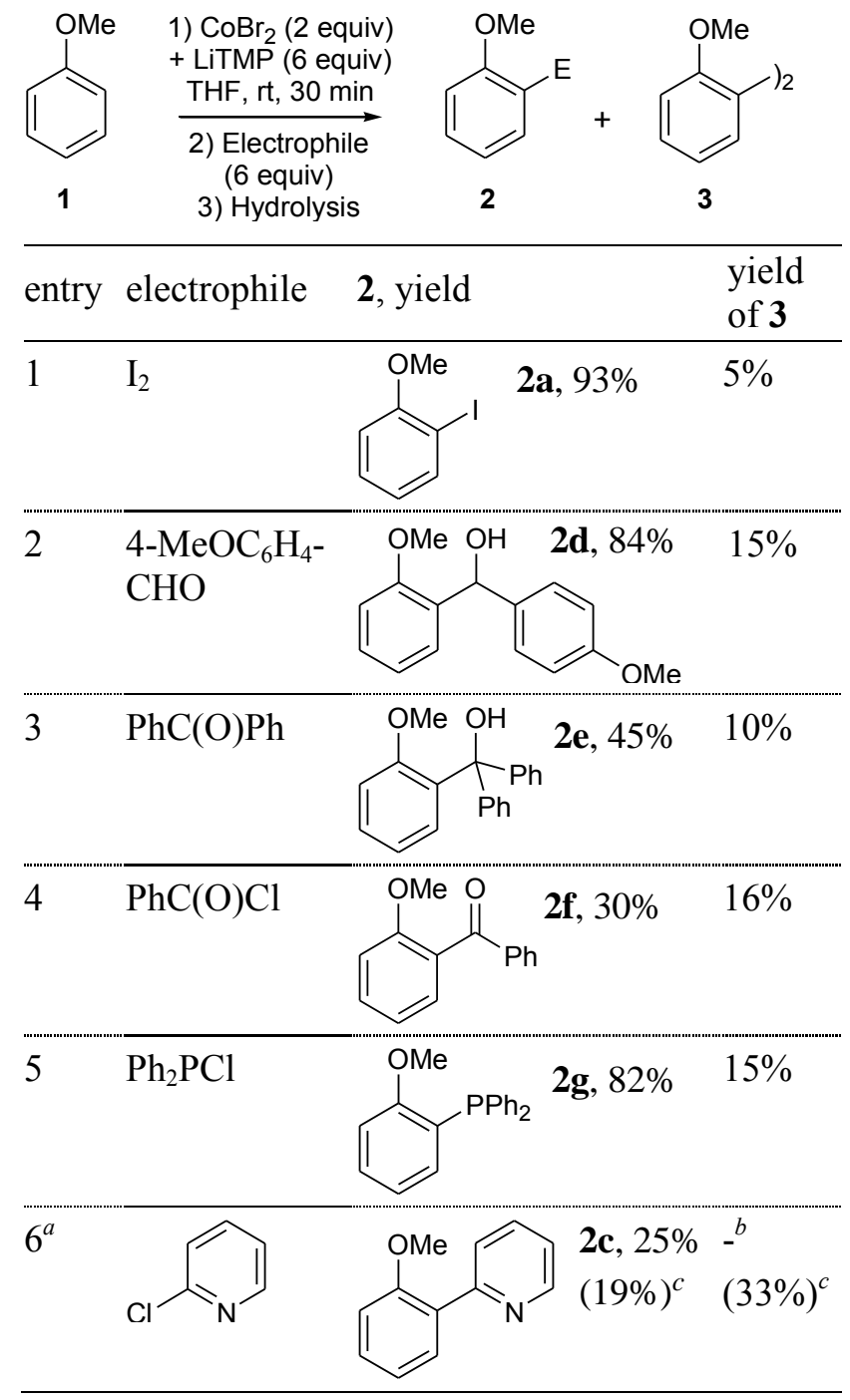

${ }^{a}$ Trapping step performed at $50{ }^{\circ} \mathrm{C}$ instead of rt. ${ }^{b}$ Not quantified. ${ }^{c}$ Using 1 equiv of base.

The method was then extended to other aromatic substrates (Table 3). Starting from 1,4-dimethoxybenzene (4) and using iodine as electrophile, the expected derivative 5a was obtained in a correct yield provided that 2 equiv of base were used (Entries 1-3). It was noted that a longer reaction time favored the co-formation of 
diiodides. Trapping with allyl bromide resulted in a significant formation of the dimer $\mathbf{6}$ whereas the expected allylated compound $\mathbf{5 b}$ was isolated in a low 6\% yield (Entry 4). These results are similar to those obtained from anisole (1). Benefiting from a greater activation, 1,3-dimethoxybenzene (7) was quantitatively converted to the iodide 8a (Entry 5). Using allyl bromide instead of iodine yielded the derivative $\mathbf{8 b}$ in a low yield due to a significant recovery of starting material; in this case, the corresponding dimer 9 was isolated in a low $6 \%$ yield (Entry 6). The behavior of 1,2-dimethoxybenzene (10) is similar to that of 1,4-dimethoxybenzene (4); the formation of the corresponding dimer 12 was suppressed by reducing the reaction time to 30 min (Entries 7 and 8). Trapping using allyl bromide led to a significant formation of the dimer $\mathbf{1 2}$, limiting the yield of the allylated derivative $\mathbf{1 1 b}$ to $23 \%$ (Entry 9). 1,2,3-Trimethoxybenzene (13) led to the expected iodide $\mathbf{1 4}$ in a moderate $33 \%$ yield, due to a significant recovery of starting material (Entry 10). Performed with 2-methoxypyridine (15), the reaction led to a more important formation of dimer than starting from methoxybenzenes. The iodide resulting from a regioselective metalation next to the methoxy group was isolated in a moderate $43 \%$ yield (Entries 11 and 12). Except an increased conversion, a similar result was observed from 2,6-dimethoxypyridine (18) (Entry 13). The method is not suitable to functionalize substrates bearing reactive functions. Indeed, using ethyl benzoate (21), side reactions with the ester function only allowed the expected iodide $\mathbf{2 2}$ to be obtained in maximum 22\% yield (Entries 14 and 15). A deprotonative metalation followed by a cross-coupling reaction was carried out from thiophene. Using 1 equiv of base (in order to avoid 2,5-dideprotonation), ${ }^{9 \mathrm{~d}}$ the expected crosscoupled compound was isolated, but in a low $19 \%$ yield (Entry 16).

TABLE 3. Extension to Other Aromatic Substrates Including Heterocycles.

$$
\begin{aligned}
& \text { 1) } \mathrm{CoBr}_{2} \text { (x equiv) } \\
& \text { + LiTMP (3x equiv) }
\end{aligned}
$$

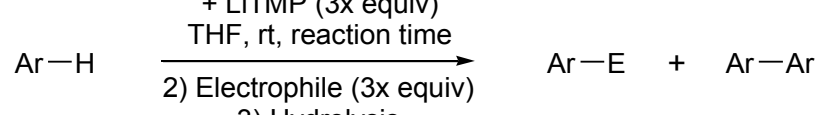

\begin{tabular}{|c|c|c|c|c|c|c|}
\hline entry & Ar-H & $\mathrm{x}$ & reaction time & electrophile & Ar-E (E), yield & Ar-Ar, yield \\
\hline 1 & 4: & 0.5 & $2 \mathrm{~h}$ & $\mathrm{I}_{2}$ & $\mathbf{5 a}(\mathrm{I}), 10 \%$ & $6,22 \%$ \\
\hline 2 & & 1 & $2 \mathrm{~h}$ & $\mathrm{I}_{2}$ & $\mathbf{5 a}(\mathrm{I}), 45 \%$ & $-^{a}$ \\
\hline 3 & & 2 & $30 \mathrm{~min}$ & $\mathrm{I}_{2}$ & $\mathbf{5 a}(\mathrm{I}), 76 \%$ & $6,10 \%$ \\
\hline 4 & & 2 & $30 \mathrm{~min}$ & $\mathrm{BrCH}_{2} \mathrm{CH}=\mathrm{CH}_{2}$ & $\mathbf{5 b}\left(\mathrm{CH}_{2} \mathrm{CH}=\mathrm{CH}_{2}\right), 6 \%$ & $\mathbf{6}, 33 \%$ \\
\hline 5 & $7:$ & 2 & $30 \mathrm{~min}$ & $\mathrm{I}_{2}$ & $\mathbf{8 a}(\mathrm{I}), 97 \%$ & \\
\hline 6 & & 2 & $30 \mathrm{~min}$ & $\mathrm{BrCH}_{2} \mathrm{CH}=\mathrm{CH}_{2}$ & $\mathbf{8 b}\left(\mathrm{CH}_{2} \mathrm{CH}=\mathrm{CH}_{2}\right), 14 \%$ & $9,6 \%$ \\
\hline
\end{tabular}

$$
\begin{aligned}
& \text { 3) Hydrolysis }
\end{aligned}
$$




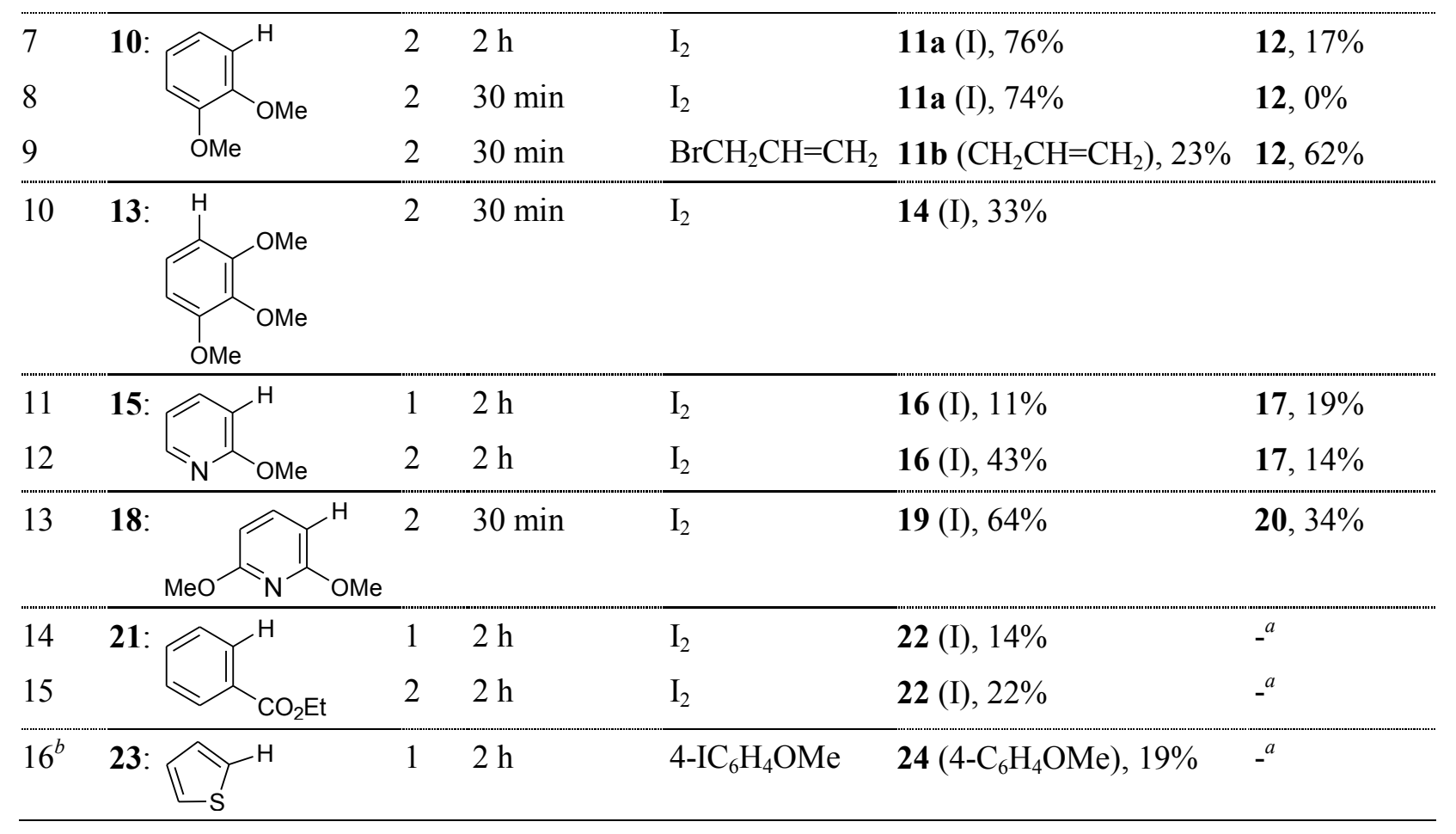

${ }^{a}$ Not quantified. ${ }^{b}$ Using 1 equiv of base.

\section{Conclusion}

Like the other lithium-metal combinations, the mixture of $\mathrm{CoBr}_{2}$ and 3 equiv of LiTMP behaves synergically, but compared with the previously described "all-TMP" lithium-zinc ${ }^{9}$ and lithiumcadmium $^{10}$ combinations, the base obtained by combining $\mathrm{CoBr}_{2}$ with 3 equiv of LiTMP is less efficient as far as both conversion and chemoselectivity are concerned. For example, starting from anisole (1), the iodide $\mathbf{2 a}$ was isolated in $84 \%$ and $75 \%$ yield using 0.5 equiv of the lithium-zinc and lithium-cadmium combinations, respectively, against 59\% under the same conditions using 1 equiv of the lithium-cobalt one. Concerning the metalation of methoxybenzenes, its efficiency more looks like that of the reported "all-TMP" Gilman-type lithium-copper(I) combination. ${ }^{11}$ Nevertheless, the reactivity exhibited by the generated arylmetal species has been improved using lithium-cobalt bases.

In conclusion, compared with the previously reported "all-TMP" reagents, the combination here presented allows more efficient direct trappings for the generated arylmetal compounds, but lacks both 
efficiency and chemoselectivity. Studies are under development to identify more suitable lithium-metal systems.

\section{Experimental Section}

\section{General Procedure A (Deprotonation using 2 equiv $\mathrm{CoBr}_{2}$ and 6 equiv LiTMP Followed by}

Trapping using $\left.\mathbf{I}_{2}\right)$. To a stirred cooled $\left(0^{\circ} \mathrm{C}\right)$ solution of 2,2,6,6-tetramethylpiperidine $(4.1 \mathrm{~mL}, 24$ $\mathrm{mmol})$ in THF $(8 \mathrm{~mL})$ were added BuLi (1.6 M hexanes solution, $24 \mathrm{mmol})$ and, $5 \mathrm{~min}$ later, $\mathrm{CoBr}_{2}$ $(1.7 \mathrm{~g}, 8.0 \mathrm{mmol})$. The mixture was stirred for $10 \mathrm{~min}$ at $0{ }^{\circ} \mathrm{C}$ before introduction of the substrate $(4.0$ $\mathrm{mmol})$. After $2 \mathrm{~h}$ at room temperature, a solution of $\mathrm{I}_{2}(6.1 \mathrm{~g}, 24 \mathrm{mmol})$ in THF $(7 \mathrm{~mL})$ was added. The mixture was stirred overnight before addition of an aq saturated solution of $\mathrm{Na}_{2} \mathrm{~S}_{2} \mathrm{O}_{3}(10 \mathrm{~mL})$ and extraction with EtOAc $(3 \times 20 \mathrm{~mL})$. The combined organic layers were dried over $\mathrm{MgSO}_{4}$, filtered and concentrated under reduced pressure.

2-Iodoanisole (2a). 2a was obtained according to the general procedure A starting from anisole (0.44 $\mathrm{mL}$ ), but reducing the metalation reaction time to $30 \mathrm{~min}$, and was isolated after purification by flash chromatography on silica gel (eluent: heptane $/ \mathrm{CH}_{2} \mathrm{Cl}_{2}$ 95/5) as a colorless oil (93\% yield). The analyses are as described previously. ${ }^{10 a}$

2-Iodo-1,4-dimethoxybenzene (5a). 5a was obtained according to the general procedure A starting from 1,4-dimethoxybenzene $(0.55 \mathrm{~g})$, but reducing the metalation reaction time to $30 \mathrm{~min}$, and was isolated after purification by flash chromatography on silica gel (eluent: heptane/AcOEt 97/3) as a yellow solid (76\% yield): $\mathrm{mp}<50{ }^{\circ} \mathrm{C} ;{ }^{1} \mathrm{H} \mathrm{NMR}\left(300 \mathrm{MHz}, \mathrm{CDCl}_{3}\right) \delta 3.74(\mathrm{~s}, 3 \mathrm{H}), 3.81(\mathrm{~s}, 3 \mathrm{H}), 6.94$ $(\mathrm{d}, 1 \mathrm{H}, J=8.9 \mathrm{~Hz}), 6.85(\mathrm{dd}, 1 \mathrm{H}, J=2.9$ and $8.9 \mathrm{~Hz}), 7.33(\mathrm{~d}, 1 \mathrm{H}, J=2.9 \mathrm{~Hz}) ;{ }^{13} \mathrm{C} \mathrm{NMR}(75 \mathrm{MHz}$, $\left.\mathrm{CDCl}_{3}\right): \delta 154.2,152.6,124.7,114.6,111.5,85.9,56.9,55.8$. These data are analogous to those previously described. $^{24}$

2,2',5,5'-Tetramethoxybiphenyl (6). 6 was obtained according to the general procedure A starting from 1,4-dimethoxybenzene (0.55 g), but using 2,2,6,6-tetramethylpiperidine (1.0 mL, 6.0 mmol), BuLi 
$(6.0 \mathrm{mmol})$ and $\mathrm{CoBr}_{2}(0.42 \mathrm{~g}, 2.0 \mathrm{mmol})$. It was isolated after purification by flash chromatography on silica gel (eluent: heptane/AcOEt 88/12) as a red solid (22\% yield): mp 94-95 ${ }^{\circ} \mathrm{C} ;{ }^{1} \mathrm{H} \mathrm{NMR}(300 \mathrm{MHz}$, $\left.\mathrm{CDCl}_{3}\right) \delta 3.73(\mathrm{~s}, 6 \mathrm{H}), 3.78(\mathrm{~s}, 6 \mathrm{H}), 6.83-6.88(\mathrm{~m}, 4 \mathrm{H}), 6.91(\mathrm{dd}, 2 \mathrm{H}, J=1.0$ and $8.4 \mathrm{~Hz}) ;{ }^{13} \mathrm{C}$ NMR $(75$ $\left.\mathrm{MHz}, \mathrm{CDCl}_{3}\right): \delta 153.3(2 \mathrm{C}), 151.1$ (2C), $128.6(2 \mathrm{C}), 117.1(2 \mathrm{C}), 113.4(2 \mathrm{C}), 112.4(2 \mathrm{C}), 56.6(2 \mathrm{C})$, 55.7 (2C). These data are analogous to those previously described. ${ }^{25}$

2-Iodo-1,3-dimethoxybenzene (8a). 8a was obtained according to the general procedure A starting from 1,3-dimethoxybenzene $(0.55 \mathrm{~g})$, but reducing the metalation reaction time to $30 \mathrm{~min}$, and was isolated after purification by flash chromatography on silica gel (eluent: heptane/AcOEt 60/40) as a white solid (97\% yield): mp $106{ }^{\circ} \mathrm{C}$ (lit. $\left.{ }^{26} 100{ }^{\circ} \mathrm{C}\right) ;{ }^{1} \mathrm{H} \mathrm{NMR}\left(300 \mathrm{MHz}, \mathrm{CDCl}_{3}\right) \delta 3.88(\mathrm{~s}, 6 \mathrm{H}), 6.49(\mathrm{~d}$, $2 \mathrm{H}, J=8.2 \mathrm{~Hz}), 7.25(\mathrm{t}, 1 \mathrm{H}, J=8.2 \mathrm{~Hz}) ;{ }^{13} \mathrm{C} \mathrm{NMR}\left(75 \mathrm{MHz}, \mathrm{CDCl}_{3}\right): \delta 159.4(2 \mathrm{C}), 129.7,104.0(2 \mathrm{C})$, $77.5,56.5(2 \mathrm{C})$.

1-Iodo-2,3-dimethoxybenzene (11a). 11a was obtained according to the general procedure A starting from veratrole $(0.50 \mathrm{~mL})$, and was isolated after purification by flash chromatography on silica gel (eluent: heptane/AcOEt 98/2) as a yellow solid (76\% yield). The analyses are as described previously. $^{10 \mathrm{a}}$

1-Iodo-2,3,4-trimethoxybenzene (14). 14 was obtained according to the general procedure A starting from 1,2,3-trimethoxybenzene $(0.68 \mathrm{~g})$, but reducing the metalation reaction time to $30 \mathrm{~min}$, and was isolated after purification by flash chromatography on silica gel (eluent: heptane $/ \mathrm{CH}_{2} \mathrm{Cl}_{2}$ 50/50) as a light yellow solid (33\% yield): $\mathrm{mp}<50{ }^{\circ} \mathrm{C}\left(\right.$ lit. $\left.{ }^{27} 42{ }^{\circ} \mathrm{C}\right) ;{ }^{1} \mathrm{H} \mathrm{NMR}\left(300 \mathrm{MHz}, \mathrm{CDCl}_{3}\right) \delta$ $3.84(\mathrm{~s}, 3 \mathrm{H}), 3.86(\mathrm{~s}, 3 \mathrm{H}), 3.87(\mathrm{~s}, 3 \mathrm{H}), 6.49(\mathrm{~d}, 1 \mathrm{H}, J=8.8 \mathrm{~Hz}), 7.40(\mathrm{~d}, 1 \mathrm{H}, J=8.8 \mathrm{~Hz}) ;{ }^{13} \mathrm{C}$ NMR $(75$ $\left.\mathrm{MHz}, \mathrm{CDCl}_{3}\right): \delta 154.3,153.3,142.6,132.5,109.7,81.2,60.9,60.8,56.1$.

3-Iodo-2-methoxypyridine (16). 16 was obtained according to the general procedure A starting from 2-methoxypyridine $(0.42 \mathrm{~mL})$, and was isolated after purification by flash chromatography on silica gel (eluent: heptane/Et $2 \mathrm{O} 85 / 15)$ as a white solid (43\% yield): $\mathrm{mp} 64{ }^{\circ} \mathrm{C}\left(\right.$ lit. $\left.^{28} 66{ }^{\circ} \mathrm{C}\right) ;{ }^{1} \mathrm{H} \mathrm{NMR}(300 \mathrm{MHz}$, 
$\left.\mathrm{CDCl}_{3}\right) \delta 3.98(\mathrm{~s}, 3 \mathrm{H}), 6.64(\mathrm{dd}, 1 \mathrm{H}, J=4.8$ and $7.5 \mathrm{~Hz}) 8.02(\mathrm{dd}, 1 \mathrm{H}, J=1.7$ and $7.5 \mathrm{~Hz}), 8.11(\mathrm{dd}$, $1 \mathrm{H}, 1.7$ and $4.8 \mathrm{~Hz}$ ); ${ }^{13} \mathrm{C}$ NMR (75 MHz, $\left.\mathrm{CDCl}_{3}\right): \delta 161.8,147.9,146.4,118.1,79.7,54.6$.

2,2'-Dimethoxybipyridine (17). 17 was obtained according to the general procedure A starting from 2-methoxypyridine ( $0.42 \mathrm{~mL})$, but using 2,2,6,6-tetramethylpiperidine (2.0 mL, $12 \mathrm{mmol})$, BuLi (12 mmol $)$ and $\mathrm{CoBr}_{2}(0.84 \mathrm{~g}, 4.0 \mathrm{mmol})$. It was isolated after purification by flash chromatography on silica gel (eluent: heptane/AcOEt 98/2) as a light yellow solid (19\% yield): mp $104{ }^{\circ} \mathrm{C}$ (lit. ${ }^{29} 139-140$ $\left.{ }^{\circ} \mathrm{C}\right) ;{ }^{1} \mathrm{H}$ NMR $\left(300 \mathrm{MHz}, \mathrm{CDCl}_{3}\right) \delta 3.92(\mathrm{~s}, 6 \mathrm{H}), 6.95(\mathrm{dd}, 2 \mathrm{H}, J=5.0$ and $7.2 \mathrm{~Hz}), 7.59(\mathrm{dd}, 2 \mathrm{H}, J=$ 1.9 and $7.2 \mathrm{~Hz}), 8.18(\mathrm{dd}, 2 \mathrm{H}, J=1.9$ and $5.0 \mathrm{~Hz}) ;{ }^{13} \mathrm{C} \mathrm{NMR}\left(75 \mathrm{MHz}, \mathrm{CDCl}_{3}\right): \delta 161.1(2 \mathrm{C}), 146.2$ (2C), $139.5(2 \mathrm{C}), 119.8(2 \mathrm{C}), 116.4(2 \mathrm{C}), 53.5(2 \mathrm{C})$.

3-Iodo-2,6-dimethoxypyridine (19). ${ }^{30} 19$ was obtained according to the general procedure A starting from 2,6-dimethoxypyridine $(0.53 \mathrm{~mL})$, but reducing the metalation reaction time to $30 \mathrm{~min}$, and was isolated after purification by flash chromatography on silica gel (eluent: heptane/AcOEt 98/2) as a brown solid (64\% yield): $\mathrm{mp}<50{ }^{\circ} \mathrm{C} ;{ }^{1} \mathrm{H}$ NMR $\left(300 \mathrm{MHz}, \mathrm{CDCl}_{3}\right) \delta 3.88(\mathrm{~s}, 3 \mathrm{H}), 3.95(\mathrm{~s}, 3 \mathrm{H}), 6.13(\mathrm{~d}$, $1 \mathrm{H}, J=8.2 \mathrm{~Hz}), 7.78(\mathrm{~d}, 1 \mathrm{H}, J=8.2 \mathrm{~Hz}) ;{ }^{13} \mathrm{C} \mathrm{NMR}\left(75 \mathrm{MHz}, \mathrm{CDCl}_{3}\right): \delta \quad 163.2,160.5,149.3,103.4$, 65.5, 54.3, 53.5; HRMS calcd for $\mathrm{C}_{7} \mathrm{H}_{8} \mathrm{INNaO}_{2}\left[(\mathrm{M}+\mathrm{Na})^{+\bullet}\right] 287.9497$ and $\mathrm{C}_{7} \mathrm{H}_{9} \mathrm{NNO}_{2}\left[(\mathrm{M}+\mathrm{H})^{+\bullet}\right]$ 265.9678, found 287.9492 and 265.9680 , respectively.

2,2',6,6'-Tetramethoxy-3,3'-bipyridine (20). ${ }^{30} \mathbf{2 0}$ was obtained according to the general procedure A starting from 2,6-dimethoxypyridine $(0.53 \mathrm{~mL})$, but reducing the metalation reaction time to $30 \mathrm{~min}$, and was isolated after purification by flash chromatography on silica gel (eluent: heptane/AcOEt 96/4) as a white solid (34\% yield): $\mathrm{mp} 144.5{ }^{\circ} \mathrm{C} ;{ }^{1} \mathrm{H}$ NMR $\left(300 \mathrm{MHz}, \mathrm{CDCl}_{3}\right) \delta 3.92(\mathrm{~s}, 6 \mathrm{H}), 3.94(\mathrm{~s}, 6 \mathrm{H})$, $6.36(\mathrm{~d}, 2 \mathrm{H}, J=8.0 \mathrm{~Hz}), 7.52(\mathrm{~d}, 2 \mathrm{H}, J=8.0 \mathrm{~Hz}) ;{ }^{13} \mathrm{C} \mathrm{NMR}\left(75 \mathrm{MHz}, \mathrm{CDCl}_{3}\right): \delta 162.0(2 \mathrm{C}), 159.6$ (2C), 142.5 (2C), $110.5(2 \mathrm{C}), 100.4$ (2C), 53.4 (2C), 53.3 (2C); HRMS calcd for $\mathrm{C}_{14} \mathrm{H}_{16} \mathrm{~N}_{2} \mathrm{NaO}_{4}$ $\left[(\mathrm{M}+\mathrm{Na})^{+\bullet}\right] 299.1008$ and $\mathrm{C}_{14} \mathrm{H}_{17} \mathrm{~N}_{2} \mathrm{O}_{4} \quad\left[(\mathrm{M}+\mathrm{H})^{+\bullet}\right] 277.1188$, found 299.1007 and 277.1192, respectively. 
Ethyl 2-iodobenzoate (22). 22 was obtained according to the general procedure A starting from ethyl benzoate $(0.61 \mathrm{~mL})$, and was isolated after purification by flash chromatography on silica gel (eluent: heptane/AcOEt 98/2) as a yellow oil (22\% yield): ${ }^{1} \mathrm{H}$ NMR $\left(300 \mathrm{MHz}, \mathrm{CDCl}_{3}\right) \delta 1.41(\mathrm{t}, 3 \mathrm{H}, J=7.1$ $\mathrm{Hz}), 4.39$ (q, 2H, $J=7.1 \mathrm{~Hz}), 7.14(\mathrm{td}, 1 \mathrm{H}, J=1.7$ and $7.8 \mathrm{~Hz}), 7.39(\mathrm{td}, 1 \mathrm{H}, J=1.7$ and $7.9 \mathrm{~Hz}), 7.79$ $(\mathrm{dd}, 1 \mathrm{H}, J=1.7$ and $7.8 \mathrm{~Hz}), 7.98(\mathrm{dd}, 1 \mathrm{H}, J=1.0$ and $7.9 \mathrm{~Hz}) ;{ }^{13} \mathrm{C} \mathrm{NMR}\left(75 \mathrm{MHz}, \mathrm{CDCl}_{3}\right): \delta 166.5$, $141.1,135.4,132.4,130.7,127.8,93.9,61.6,14.1$. These data are analogous to those previously described. $^{31}$

\section{General Procedure B (Deprotonation using 2 equiv $\mathrm{CoBr}_{2}$ and 6 equiv LiTMP Followed by} Trapping with an electrophile $\left.\neq \mathbf{I}_{2}\right)$. To a stirred cooled $\left(0{ }^{\circ} \mathrm{C}\right)$ solution of $2,2,6,6$ tetramethylpiperidine $(4.1 \mathrm{~mL}, 24 \mathrm{mmol})$ in THF $(8 \mathrm{~mL})$ were added BuLi (1.6 $\mathrm{M}$ hexanes solution, 24 mmol) and, $5 \mathrm{~min}$ later, $\mathrm{CoBr}_{2}(1.7 \mathrm{~g}, 8.0 \mathrm{mmol})$. The mixture was stirred for $10 \mathrm{~min}$ at $0{ }^{\circ} \mathrm{C}$ before introduction of the substrate $(4.0 \mathrm{mmol})$. After $30 \mathrm{~min}$ at room temperature, the electrophile $(24 \mathrm{mmol})$ was added. The mixture was stirred overnight before addition of $\mathrm{H}_{2} \mathrm{O}(10 \mathrm{~mL})$ and extraction with EtOAc ( 3 x $20 \mathrm{~mL})$. The combined organic layers were dried over $\mathrm{MgSO}_{4}$, filtered and concentrated under reduced pressure.

2-Allylanisole (2b). 2b was obtained according to the general procedure B (in this case, an extended reaction time of $2 \mathrm{~h}$ was used, and the following amounts for 2,2,6,6-tetramethylpiperidine $(2.0 \mathrm{~mL}, 12$ mmol), BuLi (12 mmol) and $\mathrm{CoBr}_{2}(0.84 \mathrm{~g}, 4.0 \mathrm{mmol})$ were used) starting from anisole $(0.44 \mathrm{~mL})$, and using allyl bromide $(1.0 \mathrm{~mL}, 12 \mathrm{mmol}) . \mathbf{2 b}$ was isolated after purification by flash chromatography on silica gel (eluent: heptane/ $\left.\mathrm{CH}_{2} \mathrm{Cl}_{2} 92 / 8\right)$ as a colorless oil ( $6 \%$ yield). The analyses are as described previously. ${ }^{10 \mathrm{e}}$

2,2'-Dimethoxybiphenyl (3). 3 was obtained according to the general procedure B (in this case, an extended reaction time of $2 \mathrm{~h}$ was used, and the following amounts for 2,2,6,6-tetramethylpiperidine (2.0 mL, $12 \mathrm{mmol})$, BuLi (12 mmol) and $\mathrm{CoBr}_{2}(0.84 \mathrm{~g}, 4.0 \mathrm{mmol})$ were used $)$ starting from anisole $(0.44 \mathrm{~mL})$, and using allyl bromide $(1.0 \mathrm{~mL}, 12 \mathrm{mmol}) .3$ was isolated after purification by flash 
chromatography on silica gel (eluent: heptane $/ \mathrm{CH}_{2} \mathrm{Cl}_{2}$ 50/50) as a white solid (38\% yield): mp $158-160$ ${ }^{\circ} \mathrm{C} ;{ }^{1} \mathrm{H}$ NMR $\left(300 \mathrm{MHz}, \mathrm{CDCl}_{3}\right) \delta 3.80(\mathrm{~s}, 6 \mathrm{H}), 7.07-6.99(\mathrm{~m}, 4 \mathrm{H}), 7.28(\mathrm{dd}, 2 \mathrm{H}, J=1.7$ and $7.4 \mathrm{~Hz})$, $7.36(\mathrm{td}, 2 \mathrm{H}, J=1.7$ and $8.2 \mathrm{~Hz}) ;{ }^{13} \mathrm{C} \mathrm{NMR}\left(75 \mathrm{MHz}, \mathrm{CDCl}_{3}\right): \delta 156.9(2 \mathrm{C}), 131.4(2 \mathrm{C}), 128.5(2 \mathrm{C})$, $127.7(2 \mathrm{C}), 120.2(2 \mathrm{C}), 111.0(2 \mathrm{C}), 55.6(2 \mathrm{C})$. These data are analogous to those previously described. $^{32}$

(2-Methoxyphenyl)(4-methoxyphenyl)methanol (2d). 2d was obtained according to the general procedure B starting from anisole $(0.44 \mathrm{~mL})$, and using anisaldehyde $(3.0 \mathrm{~mL})$. It was isolated after purification by flash chromatography on silica gel (eluent: heptane $/ \mathrm{CH}_{2} \mathrm{Cl}_{2}$ 40/60) as a light yellow oil (84\% yield). The analyses are as described previously. ${ }^{9 \mathrm{~d}}$

(2-Methoxyphenyl)diphenylmethanol (2e). 2e was obtained according to the general procedure B starting from anisole $(0.44 \mathrm{~mL})$, and using benzophenone $(4.4 \mathrm{~g})$. It was isolated after purification by flash chromatography on silica gel (eluent: heptane/Et $\left.{ }_{2} \mathrm{O} 90 / 10\right)$ as a white solid (45\% yield): mp 114.5 ${ }^{\circ} \mathrm{C}\left(1 \mathrm{it} .{ }^{33} 111-113{ }^{\circ} \mathrm{C}\right) ;{ }^{1} \mathrm{H}$ NMR $\left(300 \mathrm{MHz}, \mathrm{CDCl}_{3}\right) \delta 3.81(\mathrm{~s}, 3 \mathrm{H}), 7.08-7.01(\mathrm{~m}, 2 \mathrm{H}), 7.40-7.18(\mathrm{~m}$, 7H), 7.66-7.49 (m, 3H), 7.83-7.87 (m, 2H), OH not seen; ${ }^{13} \mathrm{C}$ NMR $\left(75 \mathrm{MHz}, \mathrm{CDCl}_{3}\right): \delta 156.9,144.1$, $131.3,128.5(4 \mathrm{C}), 128.5,127.7,127.1(4 \mathrm{C}), 126.8,120.2,110.9,82.9,55.5$.

2-Methoxybenzophenone (2f). $2 \mathrm{f}$ was obtained according to the general procedure B starting from anisole $(0.44 \mathrm{~mL})$, and using benzoyl chloride $(2.8 \mathrm{~mL})$. It was isolated after purification by flash chromatography on silica gel (eluent: heptane $/ \mathrm{CH}_{2} \mathrm{Cl}_{2}$ 50/50) as a white solid (30\% yield): mp $<50{ }^{\circ} \mathrm{C}$ (lit. $\left.{ }^{34} 35-37{ }^{\circ} \mathrm{C}\right) ;{ }^{1} \mathrm{H}$ NMR $\left(300 \mathrm{MHz}, \mathrm{CDCl}_{3}\right): \delta 3.72(\mathrm{~s}, 3 \mathrm{H}), 6.98-7.07(\mathrm{~m}, 2 \mathrm{H}), 7.34-7.58(\mathrm{~m}, 5 \mathrm{H})$, 7.79-7.83 (m, 2H); ${ }^{13} \mathrm{C} \mathrm{NMR}\left(75 \mathrm{MHz}, \mathrm{CDCl}_{3}\right): \delta 196.4,157.3,137.7,132.9,131.8,129.8(2 \mathrm{C}), 129.5$, $128.8,128.1(2 \mathrm{C}), 120.4,111.4,55.5$.

(2-Methoxyphenyl)diphenylphosphine (2g). 2g was obtained according to the general procedure B starting from anisole $(0.44 \mathrm{~mL})$, and using chlorodiphenylphosphine $(4.3 \mathrm{~mL})$. Due to its suspected easy oxidation, all the solvents were degassed before use. It was isolated after purification by flash chromatography on silica gel (eluent: heptane $\left./ \mathrm{CH}_{2} \mathrm{Cl}_{2} 85 / 15\right)$ as a white solid (82\% yield): mp $123{ }^{\circ} \mathrm{C}$ 
(lit. $\left.{ }^{35} 118{ }^{\circ} \mathrm{C}\right) ;{ }^{1} \mathrm{H}$ NMR $\left(300 \mathrm{MHz}, \mathrm{CDCl}_{3}\right) \delta 3.76(\mathrm{~s}, 3 \mathrm{H}), 6.69-6.73(\mathrm{~m}, 1 \mathrm{H}), 6.86-6.95(\mathrm{~m}, 2 \mathrm{H}), 7.28-$ $7.39(\mathrm{~m}, 11 \mathrm{H}) ;{ }^{13} \mathrm{C} \mathrm{NMR}\left(75 \mathrm{MHz}, \mathrm{CDCl}_{3}\right): \delta 161.0\left(\mathrm{~d}, J_{\mathrm{P}}=15 \mathrm{~Hz}\right), 136.6\left(\mathrm{~d}, 2 \mathrm{C}, J_{\mathrm{P}}=10 \mathrm{~Hz}\right), 133.8$ $\left(\mathrm{d}, 4 \mathrm{C}, J_{\mathrm{P}}=20 \mathrm{~Hz}\right), 133.5\left(\mathrm{~d}, J_{\mathrm{P}}=0.7 \mathrm{~Hz}\right), 130.2,128.4(2 \mathrm{C}), 128.3\left(\mathrm{~d}, 4 \mathrm{C}, J_{\mathrm{P}}=12 \mathrm{~Hz}\right), 125.5\left(\mathrm{~d}, J_{\mathrm{P}}=\right.$ $12 \mathrm{~Hz}), 120.9\left(\mathrm{~d}, J_{\mathrm{P}}=0.8 \mathrm{~Hz}\right), 110.1\left(\mathrm{~d}, J_{\mathrm{P}}=1.7 \mathrm{~Hz}\right), 55.5\left(\mathrm{~d}, J_{\mathrm{P}}=0.7\right) ;{ }^{31} \mathrm{P}$ NMR $\left(75 \mathrm{MHz}, \mathrm{CDCl}_{3}\right): \delta$ -16.8; HRMS calcd for $\mathrm{C}_{19} \mathrm{H}_{17} \mathrm{NaOP}\left[(\mathrm{M}+\mathrm{Na})^{+\bullet}\right] 315.0915$ and $\mathrm{C}_{19} \mathrm{H}_{18} \mathrm{OP}\left[(\mathrm{M}+\mathrm{H})^{+\bullet}\right] 2$ 293.1095, found 315.0913 and 293.1094, respectively.

2-(2-Methoxyphenyl)pyridine (2c). 2c was obtained according to the general procedure B, but performing the trapping step at $50{ }^{\circ} \mathrm{C}$, starting from anisole $(0.44 \mathrm{~mL})$, and using 2-chloropyridine $(2.3$ $\mathrm{mL}$ ). It was isolated after purification by flash chromatography on silica gel (eluent: heptane/AcOEt $90 / 10)$ as a yellow oil (25\% yield). The analyses are as described previously. ${ }^{9 \mathrm{~d}}$

2-Allyl-1,4-dimethoxybenzene (5b). 5b was obtained according to the general procedure B starting from 1,4-dimethoxybenzene $(0.55 \mathrm{~g})$, and using allyl bromide $(2.1 \mathrm{~mL})$. It was isolated after purification by flash chromatography on silica gel (eluent: heptane/EtOAc 98/2) as a colorless oil (6\% yield): ${ }^{1} \mathrm{H}$ NMR (300 MHz, $\left.\mathrm{CDCl}_{3}\right) \delta 3.36$ (d, 2H, $\left.J=6.6 \mathrm{~Hz}\right), 3.76(\mathrm{~s}, 3 \mathrm{H}), 3.78(\mathrm{~s}, 3 \mathrm{H}), 5.01-5.14$ (m, 2H), 6.10-5.90 (m, 1H), 6.92-6.68 (m, 3H); ${ }^{13} \mathrm{C} \mathrm{NMR}\left(75 \mathrm{MHz}, \mathrm{CDCl}_{3}\right): \delta 153.5,151.5,136.7,129.8$, 116.1, 115.5, 111.4, 111.3, 56.0, 55.6, 34.2. The ${ }^{1} \mathrm{H}$ NMR data are analogous to those described. ${ }^{36}$

2-Allyl-1,3-dimethoxybenzene ( $\mathbf{8 b}) .{ }^{37} \mathbf{8 b}$ was obtained according to the general procedure B starting from 1,3-dimethoxybenzene $(0.55 \mathrm{~g})$, and using allyl bromide $(2.1 \mathrm{~mL})$. It was isolated after purification by flash chromatography on silica gel (eluent: heptane/ $\mathrm{CH}_{2} \mathrm{Cl}_{2} 90 / 10$ ) as a colorless oil (14\% yield): ${ }^{1} \mathrm{H}$ NMR (300 MHz, $\left.\mathrm{CDCl}_{3}\right) \delta 3.42(\mathrm{dt}, 2 \mathrm{H}, J=1.5$ and $6.1 \mathrm{~Hz}), 3.81(\mathrm{~s}, 6 \mathrm{H}), 4.90-5.00$ $(\mathrm{m}, 2 \mathrm{H}), 5.89-6.02(\mathrm{~m}, 1 \mathrm{H}), 6.56(\mathrm{~d}, 2 \mathrm{H}, J=8.3 \mathrm{~Hz}), 7.14(\mathrm{t}, 1 \mathrm{H}, J=8.3 \mathrm{~Hz}) ;{ }^{13} \mathrm{C}$ NMR $(75 \mathrm{MHz}$, $\left.\mathrm{CDCl}_{3}\right): \delta 158.2(2 \mathrm{C}), 136.8,127.0,116.5,113.9,103.8(2 \mathrm{C}), 55.8(2 \mathrm{C}), 27.1$.

2,2',6,6'-Tetramethoxybiphenyl (9). 9 was obtained according to the general procedure B starting from 1,3-dimethoxybenzene $(0.55 \mathrm{~g})$, and using allyl bromide $(2.1 \mathrm{~mL})$. It was isolated after purification by flash chromatography on silica gel (eluent: heptane/ $\left.\mathrm{CH}_{2} \mathrm{Cl}_{2} 30 / 70\right)$ as a white solid $(6 \%$ 
yield): mp $176{ }^{\circ} \mathrm{C}\left(\right.$ lit. $\left.^{37} 174-175^{\circ} \mathrm{C}\right) ;{ }^{1} \mathrm{H}$ NMR $\left(300 \mathrm{MHz}, \mathrm{CDCl}_{3}\right) \delta 3.72(\mathrm{~s}, 12 \mathrm{H}), 6.65$ (d, 4H, $J=8.3$ $\mathrm{Hz}), 7.29(\mathrm{t}, 2 \mathrm{H}, J=8.3 \mathrm{~Hz}) ;{ }^{13} \mathrm{C} \mathrm{NMR}\left(75 \mathrm{MHz}, \mathrm{CDCl}_{3}\right): \delta 158.3(4 \mathrm{C}), 128.6(2 \mathrm{C}), 112.5(2 \mathrm{C}), 104.4$ (4C), $56.1(4 \mathrm{C})$. These data are analogous to those previously described. ${ }^{38}$

1-Allyl-2,3-dimethoxybenzene (11b). ${ }^{39}$ 11b was obtained according to the general procedure B starting from veratrole $(0.50 \mathrm{~mL})$, and using allyl bromide $(2.1 \mathrm{~mL})$. It was isolated after purification by flash chromatography on silica gel (eluent: heptane/AcOEt 98/2) as a colorless oil (23\% yield): ${ }^{1} \mathrm{H}$ NMR (300 MHz, $\left.\mathrm{CDCl}_{3}\right) \delta 3.42(\mathrm{~d}, 2 \mathrm{H}, J=6.5 \mathrm{~Hz}), 3.81(\mathrm{~s}, 3 \mathrm{H}), 3.86(\mathrm{~s}, 3 \mathrm{H}), 5.02-5.10(\mathrm{~m}, 2 \mathrm{H})$, 5.91-6.05 (m, 1H), 6.76-6.81 (m, 2H), $7.00(\mathrm{t}, 1 \mathrm{H}, J=7.8 \mathrm{~Hz}) ;{ }^{13} \mathrm{C} \mathrm{NMR}\left(75 \mathrm{MHz}, \mathrm{CDCl}_{3}\right): \delta 152.7$, $147.0,137.2,133.9,123.8,121.9,115.4,110.4,60.5,55.6,33.9$.

2,2',3,3'-Tetramethoxybiphenyl (12). 12 was obtained according to the general procedure B starting from veratrole $(0.50 \mathrm{~mL})$, and using allyl bromide $(2.1 \mathrm{~mL})$. It was isolated after purification by flash chromatography on silica gel (eluent: heptane/AcOEt 88/12) as a white solid (62\% yield): mp 106-108 ${ }^{\circ} \mathrm{C}\left(\right.$ lit. $\left.^{40}{ }^{104-105}{ }^{\circ} \mathrm{C}\right) ;{ }^{1} \mathrm{H}$ NMR $\left(300 \mathrm{MHz}, \mathrm{CDCl}_{3}\right) \delta 3.65(\mathrm{~s}, 6 \mathrm{H}), 3.90(\mathrm{~s}, 6 \mathrm{H}), 6.87$ (dd, 2H, $J=1.6$ and $7.6 \mathrm{~Hz}), 6.93(\mathrm{dd}, 2 \mathrm{H}, J=1.6$ and $8.2 \mathrm{~Hz}), 7.08(\mathrm{dd}, 2 \mathrm{H}, J=7.6$ and $8.2 \mathrm{~Hz}) ;{ }^{13} \mathrm{C}$ NMR $(75 \mathrm{MHz}$, $\left.\mathrm{CDCl}_{3}\right): \delta 152.7(2 \mathrm{C}), 146.7(2 \mathrm{C}), 132.8(2 \mathrm{C}), 123.2(2 \mathrm{C}), 123.2(2 \mathrm{C}), 111.5(2 \mathrm{C}), 60.5(2 \mathrm{C}), 55.7$ (2C); HRMS calcd for $\mathrm{C}_{16} \mathrm{H}_{18} \mathrm{NaO}_{4}\left[(\mathrm{M}+\mathrm{Na})^{+\bullet}\right] 297.1103$ and $\mathrm{C}_{16} \mathrm{H}_{18} \mathrm{KO}_{4}\left[(\mathrm{M}+\mathrm{K})^{+\bullet}\right] 313.0842$, found 297.1104 and 313.0854, respectively.

2-(4-Methoxyphenyl)thiophene (24). 24 was obtained according to the general procedure B starting from thiophene (0.32 g), but using 2,2,6,6-tetramethylpiperidine (2.0 mL, $12 \mathrm{mmol})$, BuLi (12 mmol) and $\mathrm{CoBr}_{2}(0.84 \mathrm{~g}, 4.0 \mathrm{mmol})$. It was isolated after purification by flash chromatography on silica gel (eluent: heptane) as a yellow solid (19\% yield). The analyses are as described previously. ${ }^{10 \mathrm{e}}$

Acknowledgments. The authors gratefully acknowledge the financial support of Agence Nationale de la Recherche (ACTIVATE program) (to G. D.). They thank Rennes Métropole and the Institut Universitaire de France. 


\section{References and Notes}

(1) (a) Gschwend, H. W.; Rodriguez, H. R. Org. React. 1979, 26, 1-360. (b) Beak, P.; Snieckus, V. Acc. Chem. Res. 1982, 15, 306-312. (c) Snieckus, V. Chem. Rev. 1990, 90, 879-933. (d) Gant, T. G.; Meyers, A. I. Tetrahedron 1994, 50, 2297-2360. (e) Schlosser, M. Organometallics in Synthesis 2002, 2nd ed. (Ed.: Schlosser, M.), Wiley, 2002, Chapter I.

(2) Schlosser, M. Pure Appl. Chem. 1988, 60, 1627-1634.

(3) Lochmann, L. Eur. J. Inorg. Chem. 2000, 7, 1115-1126.

(4) Gros, P. C.; Fort, Y. Eur. J. Org. Chem. 2009, 4199-4209, and references cited therein.

(5) (a) Mulvey, R. E. Organometallics 2006, 25, 1060-1075. (b) Mulvey, R. E.; Mongin, F.; Uchiyama, M.; Kondo, Y. Angew. Chem. Int. Ed. 2007, 46, 3802-3824. (c) Mulvey, R. E. Acc. Chem. Res. 2009, 42, 743-755.

(6) (a) Clegg, W.; Dale, S. H.; Drummond, A. M.; Hevia, E.; Honeyman, G. W.; Mulvey, R. E. J. Am. Chem. Soc. 2006, 128, 7434-7435. (b) Clegg, W.; Conway, B.; Hevia, E.; McCall, M. D.; Russo, L.; Mulvey, R. E. J. Am. Chem. Soc. 2009, 131, 2375-2384.

(7) Alborés, P.; Carrella, L. M.; Clegg, W.; García-Álvarez, P.; Kennedy, A. R.; Klett, J.; Mulvey, R. E.; Rentschler, E.; Russo, L. Angew. Chem. Int. Ed. 2009, 48, 3317-3321.

(8) Wunderlich, S. H.; Knochel, P. Angew. Chem. Int. Ed. 2009, 48, 9717-9720.

(9) (a) Seggio, A.; Lannou, M. I.; Chevallier, F.; Nobuto, D.; Uchiyama, M.; Golhen, S.; Roisnel, T.; Mongin, F. Chem. Eur. J. 2007, 13, 9982-9989. (b) Seggio, A.; Chevallier, F.; Vaultier, M.; Mongin, F. J. Org. Chem. 2007, 72, 6602-6605. (c) L'Helgoual'ch, J. M.; Seggio, A.; Chevallier, F.; Yonehara, M.; Jeanneau, E.; Uchiyama, M.; Mongin, F. J. Org. Chem. 2008, 73, 177-183. (d) Snégaroff, K.; Komagawa, S.; Chevallier, F.; Gros, P. C.; Golhen, S.; Roisnel, T.; Uchiyama, M.; Mongin, F. Chem. Eur. J. 2010, 16, 8191-8201.

(10) (a) L'Helgoual'ch, J. M.; Bentabed-Ababsa, G.; Chevallier, F.; Yonehara, M.; Uchiyama, M.; Derdour, A.; Mongin, F. Chem. Commun. 2008, 5375-5377. (b) L'Helgoual'ch, J. M.; BentabedAbabsa, G.; Chevallier, F.; Derdour, A.; Mongin, F. Synthesis 2008, 4033-4035. (c) BentabedAbabsa, G.; Blanco, F.; Derdour, A.; Mongin, F.; Trécourt, F.; Queguiner, G.; Ballesteros, R.; Abarca, B. J. Org. Chem. 2009, 74, 163-169. (d) Snégaroff, K.; Lassagne, F.; Bentabed-Ababsa, G.; Nassar, E.; Cheikh Sid Ely, S.; Hesse, S.; Perspicace, E.; Derdour, A.; Mongin, F. Org. Biomol. Chem. 2009, 7, 4782-4788. (e) Snégaroff, K.; L'Helgoual'ch, J. M.; Bentabed-Ababsa, G.; Nguyen, T. T.; Chevallier, F.; Yonehara, M.; Uchiyama, M.; Derdour, A.; Mongin, F. Chem. Eur. J. 2009, 15, 10280-10290. (f) Bentabed-Ababsa, G.; Cheikh Sid Ely, S.; Hesse, S.; Nassar, E.; Chevallier, F.; Nguyen, T. T.; Derdour, A.; Mongin, F. J. Org. Chem. 2010, 75, 839-847. (g) Snégaroff, K.; Komagawa, S.; Yonehara, M.; Chevallier, F.; Gros, P. C.; Uchiyama, M.; Mongin, F. J. Org. Chem. 2010, 75, 3117-3120.

(11) Nguyen, T. T.; Chevallier, F.; Jouikov, V.; Mongin, F. Tetrahedron Lett. 2009, 50, 6787-6790.

(12) (a) Corey, E. J.; Posner, G. H. Tetrahedron Lett. 1970, 11, 315-318. (b) Andersen, R. A.; Carmona-Guzman, E.; Mertis, K.; Sigurdson, E.; Wilkinson, G. J. J. Organomet. Chem. 1975, 99, C19-C20. (c) Kauffmann, T. Angew. Chem., Int. Ed. Engl. 1996, 35, 386-403.

(13) Ohmiya, H.; Yorimitsu, H.; Oshima, K. Angew. Chem. Int. Ed. 2005, 44, 3488-3490.

(14) Au-Yeung, H. Y.; Lam, C. H.; Lam, C.-K.; Wong, W.-Y.; Lee, H. K. Inorg. Chem. 2007, 46, 7695-7697.

(15) Sacconi, L.; Bertini, I.; Mani, F. Inorg. Chem. 1967, 6, 262-267.

(16) $\mathrm{CoBr}_{2}$, more soluble than $\mathrm{CoCl}_{2}$, was chosen to replace $\mathrm{CoCl}_{2} \bullet \mathrm{TMEDA}$.

(17) Uchiyama, M.; Kameda, M.; Mishima, O.; Yokoyama, N.; Koike, M.; Kondo, Y.; Sakamoto, T. J. Am. Chem. Soc. 1998, 120, 4934-4946.

(18) (a) Gosmini, C.; Begouin, J.-M.; Moncomble, A. Chem. Commun. 2008, 3221-3233. (b) Hess, W.; Treutwein, J.; Hilt, G. Synthesis 2008, 3537-3562. 
(19) (a) Mayer, M.; Czaplik, W. M.; Jacobi von Wangelin, A. Synlett 2009, 2931-2934. (b) Chen, S.Y.; Zhang, J.; Li, Y.-H.; Wen, J.; Bian, S.-Q.; Yu, X.-Q. Tetrahedron Lett. 2009, 50, 67956797.

(20) Scott, J.; Gambarotta, S.; Korobkov, I. Can. J. Chem. 2005, 83, 279-285.

(21) The use of $\mathrm{Zn}$ as reductant did not change the yield of $\mathbf{3}$ either.

(22) The use of nitrobenzene or chloranil did not change the yield of $\mathbf{3}$ either.

(23) (a) Wakabayashi, K.; Yorimitsu, H.; Oshima, K. J. Am. Chem. Soc. 2001, 123, 5374-5375. (b) Affo, W.; Ohmiya, H.; Fujioka, T.; Ikeda, Y.; Nakamura, T.; Yorimitsu, H.; Oshima, K.; Imamura, Y.; Mizuta, T.; Miyoshi, K. J. Am. Chem. Soc. 2006, 128, 8068-8077.

(24) Yamaguchi, Y.; Matsubara, Y.; Ochi, T.; Wakamiya, T.; Yoshida, Z.-i. J. Am. Chem. Soc. 2008, 130, 13867-13869.

(25) Kania-Korwel, I.; Parkin, S.; Robertson, L. W.; Lehmler, H.-J. Chemosphere 2004, 56, 735-744.

(26) Uchiyama, M.; Naka, H.; Matsumoto, Y.; Ohwada, T. J. Am. Chem. Soc. 2004, 126, 1052610527.

(27) Wirth, H. O.; Konigstein, O.; Kern, W. Justus Liebigs Ann. Chem. 1960, 634, 84-104.

(28) Naka, H.; Uchiyama, M.; Matsumoto, Y.; Wheatley, A. E. H.; McPartlin, M.; Morey, J. V.; Kondo, Y. J. Am. Chem. Soc. 2007, 129, 1921-1930.

(29) Tiecco, M.; Testaferri, L.; Tingoli, M.; Chianelli, D.; Montanucci, M. Synthesis 1984, 736-738.

(30) Marcuccio, S. M.; Rodopoulos, M.; Weingold, H.; 1998, WO 98-AU245 9845265.

(31) Zhdankin, V. V.; Koposov, A. Y.; Litvinov, D. N.; Ferguson, M. J.; McDonald, R.; Luu, T.; Tykwinski, R. R. J. Org. Chem. 2005, 70, 6484-6491.

(32) Cepanec, I.; Litvić, M.; Udiković, J.; Pogorelić, I.; Lovrić, M. Tetrahedron 2007, 63, 56145621.

(33) Chen, Q.; Huang, J. Polym. Int. 2006, 55, 19-24.

(34) Elderfield, R. C.; King, T. P. J. Am. Chem. Soc. 1954, 76, 5439-5445.

(35) Horner, L.; Simons, G. Phosphorus, Sulfur Relat. Elem. 1983, 14, 189-209.

(36) Ochiai, M.; Fujita, E.; Arimoto, M.; Yamaguchi, H. Chem. Pharm. Bull. 1982, 30, 3994-3999.

(37) Kaliakoudas, D.; Eugster, C. H.; Ruedi, P. Helv. Chim. Acta 1990, 73, 48-62.

(38) Govender, S.; Mmutlane, E. M.; van Otterlo, W. A. L.; de Koning, C. B. Org. Biomol. Chem. 2007, 5, 2433-2440.

(39) Kikuchi, Y.; Hasegawa, Y.; Matsumoto, M. Tetrahedron Lett. 1982, 23, 2199-2202.

(40) Gilman, H.; Swiss, J.; Cheney, L. C. J. Am. Chem. Soc. 1940, 62, 1963-1967. 